\title{
Cetacean occurrence in the Santa Marta Region, Colombian Caribbean, February-May 2007 ${ }^{1}$
}

\author{
Natalia Fraija ${ }^{2 *}$, Lilián Flórez-GonZálezZ ${ }^{3}$ and Aminta Jáuregui ${ }^{4}$
}

Until recently, cetacean presence in the Santa Marta region of the Colombian Caribbean was poorly documented and limited to incidental reports (Cuervo et al., 1986; PrietoRodríguez, 1988; Vidal, 1990; Flórez-González and Torres, 19945; Flórez-González and Capella-Alzueta, 1995; FlórezGonzález et al., 2004). Continued presence and interest by researchers in the area since the early 2000's has resulted in significant new information, including a better understanding of species occurrence, environmental influences, and human impacts on the local populations (Pardo and Palacios, 2006; Jiménez-Pinedo and DomínguezGarcía, 2007; Lozano, 2007). With the aim of providing continuity to the study of cetaceans in the region, this study reports on the cetacean community around Santa Marta during the first months of 2007. We evaluate our methods and results in the context of these recent studies and provide recommendations for future research in the region.

Santa Marta's coastal zone is highly variabile over the course of the year in water temperature, salinity, and fisheries yields (Manjarrés et al., 19936). Input from deep, nutrient-rich waters $(150-200 \mathrm{~m})$ to the surface takes place during December to April (the dry season) as a result of wind-driven coastal upwelling, which also increases salinity up to $36.5 \%$ ond lowers water temperatures to $22-25^{\circ} \mathrm{C}$. For the rest of the year (the rainy season) a surface countercurrent enters the region from the south, decreasing salinity values and increasing water temperatures (Fajardo, 1978; Bula-Meyer, 1990; Díaz-Merlano, 19907; Ramírez, 1990\%; Andrade-Amaya, 2001; Franco-Herrera, 2005). The abrupt geomorphology of the region is determined by the presence of the Sierra Nevada de Santa Marta, whose foothills extend to the coast, resulting in an absence of a continental shelf and leading to water depths up to $100 \mathrm{~m}$ at distances between 0.5 and $6 \mathrm{~km}$ from the coast, and resulting in an intricate system of bays, coves and rocky shores (Andrade, 1988; Díaz-Merlano, 19907; Díaz-Merlano and Gómez, $2000^{10}$ ). The presence of deep waters close to shore confers the coastal environment an oceanic character (Bula-Meyer, 1990; Franco-Herrera, 2005²).

The study was conducted between Gaira Bay $\left(11^{\circ} 12^{\prime} \mathrm{N}\right.$, $\left.74^{\circ} 15^{\prime} \mathrm{W}\right)$ and Arrecifes $\left(11^{\circ} 20^{\prime} \mathrm{N}, 73^{\circ} 57^{\prime} \mathrm{W}\right)$, in the Tayrona National Natural Park (TNNP), during February and May 2007 (Figure 1). Observations from land-based stations (42.2hr in 17 days) were conducted on key outposts located at a height of about $15 \mathrm{~m}$ above sea level using Minolta ${ }^{\circledR}$ $8 \times 40$ binoculars with a vision range of $8.2^{\circ}$ and $143 \mathrm{~m}$. Additionally, 16 boat-based surveys $(83.0 \mathrm{hr})$ were carried out systematically over a $36.7 \mathrm{~km}$ transect running parallel to the coastline at a distance of $1 \mathrm{~km}$ from shore. The boat, with $9 \mathrm{~m}$ length, had an effective visual range of about $2 \mathrm{~km}$ and operated at a survey speed of about $9.6 \mathrm{~km} / \mathrm{hr}$, slowing down whenever a group of animals was encountered. Two trained observers were constantly looking out, in sea-state conditions of Beaufort $<4$. Shape and color pattern of the animals and appropriate photographic material was collected, as well as data concerning time and location of the sighting, number of individuals, heading of the animals, surface behavior, sea state and visibility. In addition to the shore-based and boat surveys, incidental sightings collected by third parties with training on marine

${ }^{1}$ Received on 7 February 2009. Accepted on 20 October 2009. Managed by Daniel Palacios.

${ }^{2}$ Facultad de Ciencias Biológicas, Universidad de Valencia, Calle Dr. Moliner, 50, Burjassot, Valencia, España.

${ }^{3}$ Fundación Yubarta, Carrera 24 No. 4-32, Cali, Colombia.

${ }^{4}$ Facultad de Biología Marina, Universidad Jorge Tadeo Lozano, Carrera 2 No. 11-68, Edificio Mundo Marino, Rodadero, Santa Marta, Colombia.

* Corresponding author, e-mail: natalia.fraija@gmail.com.

${ }^{5}$ Flórez-González, L. and Torres, D. (1994) Presencia de la ballena tropical Balaenoptera edeni y ballena yubarta Megaptera novaeangliae en la región de Santa Marta, Caribe colombiano. Page 83 in Abstracts, IX Seminario Nacional de Ciencias y Tecnologías del Mar y Congreso Latinoamericano de ciencias del mar, 21-25 November, Medellín, Colombia.

${ }^{6}$ Manjarrés, L., Infante, J., Rueda, A. and Escorica, F. (1993) Evaluación de captura y esfuerzo pesquero en el área marítima de Santa Marta. Instituto Nacional de Pesca y Agricultura-INPA, Centro Internacional de Investigación para el Desarrollo-CIID, Proyecto integral de investigaciones y desarrollo de la pesca artesanal marítima en el área de Santa Marta: Pages 21-43. [Available from Universidad del Magdalena, Santa Marta, Colombia].

${ }^{7}$ Díaz-Merlano, J.M. (Ed.) (1990) Estudio ecológico integrado de la zona costera de Santa Marta y Parque Nacional Natural Tayrona. Project final report: 439pp. [Available from INVEMAR, Santa Marta, Colombia].

${ }^{8}$ Ramírez, G. (1990) Distribución de los nutrientes inorgánicos en las aguas costeras de la región de Santa Marta. Caribe colombiano. Pages 244-254 in Proceedings, VII Seminario Nacional de Ciencias y Tecnologías del Mar. Comisión Colombiana de Oceanografía, 30 October - 2 November, Cali, Colombia.

${ }^{9}$ Franco-Herrera, A. (2005) Oceanografía de la Ensenada de Gaira-El Rodadero, más que un centro turístico en el Caribe colombiano: 56 pp. [Available from Universidad Jorge Tadeo Lozano, Santa Marta, Colombia].

${ }^{10}$ Díaz-Merlano, J.M. and Gómez, D.I. (2000) Programa Nacional de Investigación en Biodiversidad Marina y Costera-PNIMB. Fondo Financiero de Proyectos de Desarrollo-FONADE, Ministerio de Medio Ambiente. [Available from Instituto de Investigaciones MarinasINVEMAR, Santa Marta, Colombia]. 


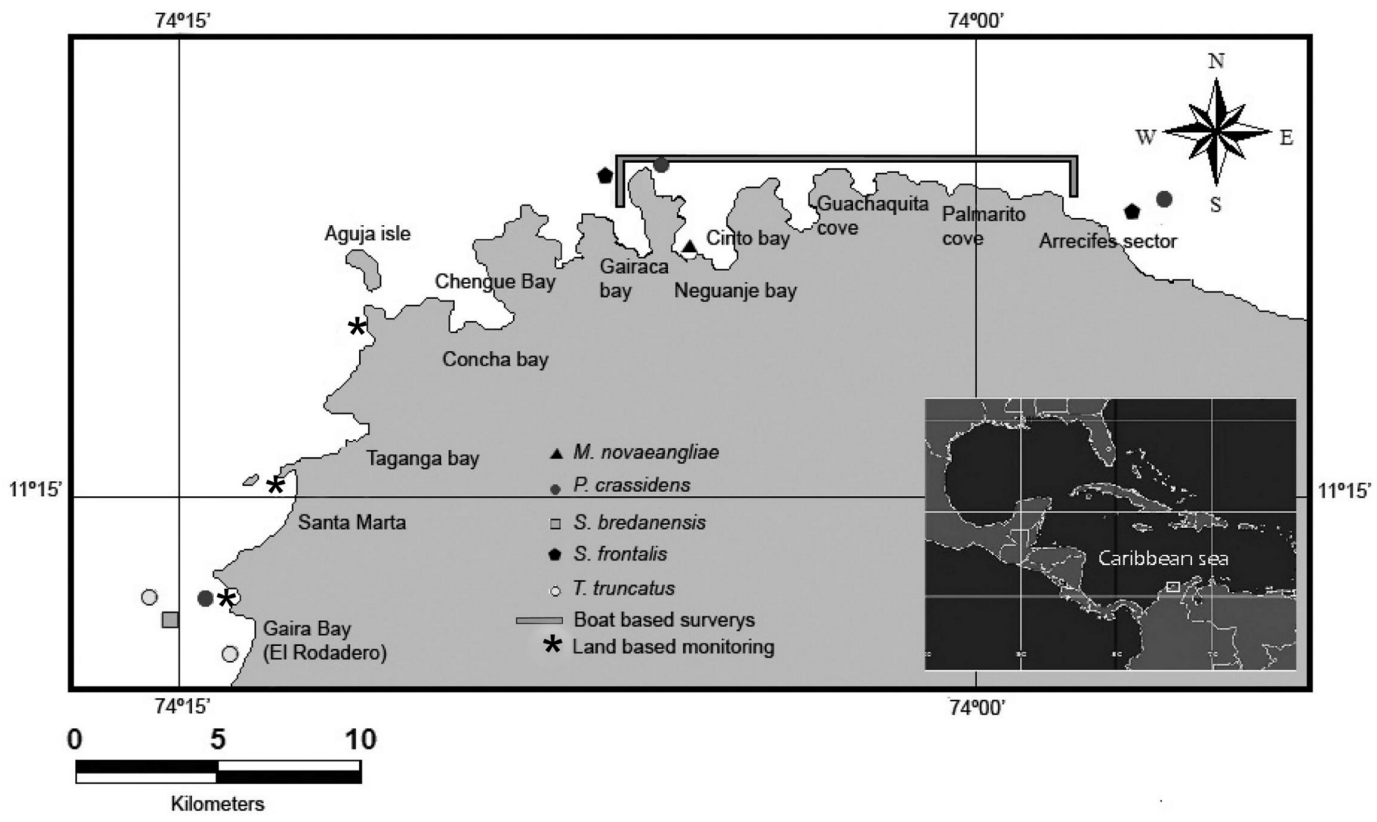

Figure 1. Study area showing land-based monitoring areas (open triangles), the typical track of the boat-based surveys (thick line), and the location of the cetacean observations (filled symbols).

mammal identification and supported with adequate photographic and filmic material are considered here as supplemental information.

To obtain an environmental context for the presence of the various cetacean species recorded during the study, oceanographic data was obtained from the Oceanographic and Hydrographic Investigation Center $(\mathrm{CIOH})$ and from the Jorge Tadeo Lozano University's SURDEMAG Program, which focuses on the study of upwelling dynamics in Magdalena, the political department to which the Santa Marta region belongs. Bathymetric and ocean floor charts were obtained from the Instituto de Investigaciones Marinas y Costeras (INVEMAR). Finally, ichthyic material was sampled from the landings by the local artisanal fisheries.

Humpback whale (Megaptera novaeangliae) - On 21 April 2007 , the carcass of an animal measuring $6.15 \mathrm{~m}$ was found ashore in Neguanje Bay (Table 1, Figure 1), in a high level of decomposition. Unidentified ectoparasites and a deep, circular perforation $(10 \mathrm{~cm}$ diameter) in the caudal peduncle were observed (Figure 3c-d). Due to the decomposition level it was not possible to ascertain the cause of death; however samples of skin, blubber and vertebrae were collected and deposited at the Jorge Tadeo Lozano University for future study.

According to the mean length at birth of this species (4.5m) (Clapham and Mead, 1999) the animal was a calf. The humpback whale has only been occasionally reported in the Colombian Caribbean (Vidal, 1990; Flórez-González and Capella-Alzueta, 1995). Individuals from the North Atlantic population gather in the southeastern Caribbean during mid-February and mid-March, where nursing, mating and calving occurs (Swartz, et al., 2003). Therefore, it is quite possible that the stranded calf belonged to this population. Studies documenting the presence of the humpback whale in the Colombian Caribbean are needed, focusing on determining the relationship between animals found in the southwestern Caribbean to those elsewhere.

Table 1. Summary of cetacean observations collected in the Santa Marta region during the survey.

\begin{tabular}{lccccl}
\hline \hline $\begin{array}{l}\text { DATE } \\
\text { DD/MM/YY }\end{array}$ & SPECIES & LOCATION & $\begin{array}{c}\text { GROUP } \\
\text { COMPOSITION }\end{array}$ & $\begin{array}{c}\text { TYPE OF } \\
\text { EVENT }\end{array}$ & $\begin{array}{c}\text { SURFACE } \\
\text { EVENTS }\end{array}$ \\
\hline \hline $07 / 01 / 07$ & Pseudorca crassidens & Gaira bay & Und. & Ind. & Trav. \\
$13 / 01 / 07$ & Tursiops truncatus & Gaira bay & Und. & Ind. & Und. \\
$14 / 02 / 07$ & Stenella frontalis & Gairaca bay & $3(\mathrm{~A} / \mathrm{J})$ & Dir. & Rest. \\
$17 / 02 / 07$ & Pseudorca crassidens & Arrecifes sector & $22($ Und. & Dir. & Trav. \\
$18 / 02 / 07$ & Tursiops truncatus & Gaira bay & Und. & Ind. & Und. \\
$24 / 02 / 07$ & Stenella frontalis & Arrecifes sector & $23(\mathrm{~A} / \mathrm{J} / \mathrm{C})$ & Dir. & Trav. \\
$04 / 03 / 07$ & Pseudorca crassidens & Neguanje bay & $30(\mathrm{~A} / \mathrm{J})$ & Dir. & Feed. \\
$15 / 03 / 07$ & Steno bredanensis & Gaira bay & $30(\mathrm{~A} / \mathrm{J})$ & Dir. & Feed. \\
$21 / 04 / 07$ & Megaptera novaeangliae & Neguanje bay & $1(\mathrm{C})$ & Stran. & N/A \\
\hline \hline
\end{tabular}

Und. = undetermined; $\mathrm{A}$ = adults; $\mathrm{J}=$ juveniles; $\mathrm{C}=$ calf; Ind. = indirect sighting; Dir. = direct sighting; Stran. = stranding; Rest. $=$ resting; Trav. $=$ traveling; Feed. $=$ feeding; $\mathrm{N} / \mathrm{A}=$ not applicable. 


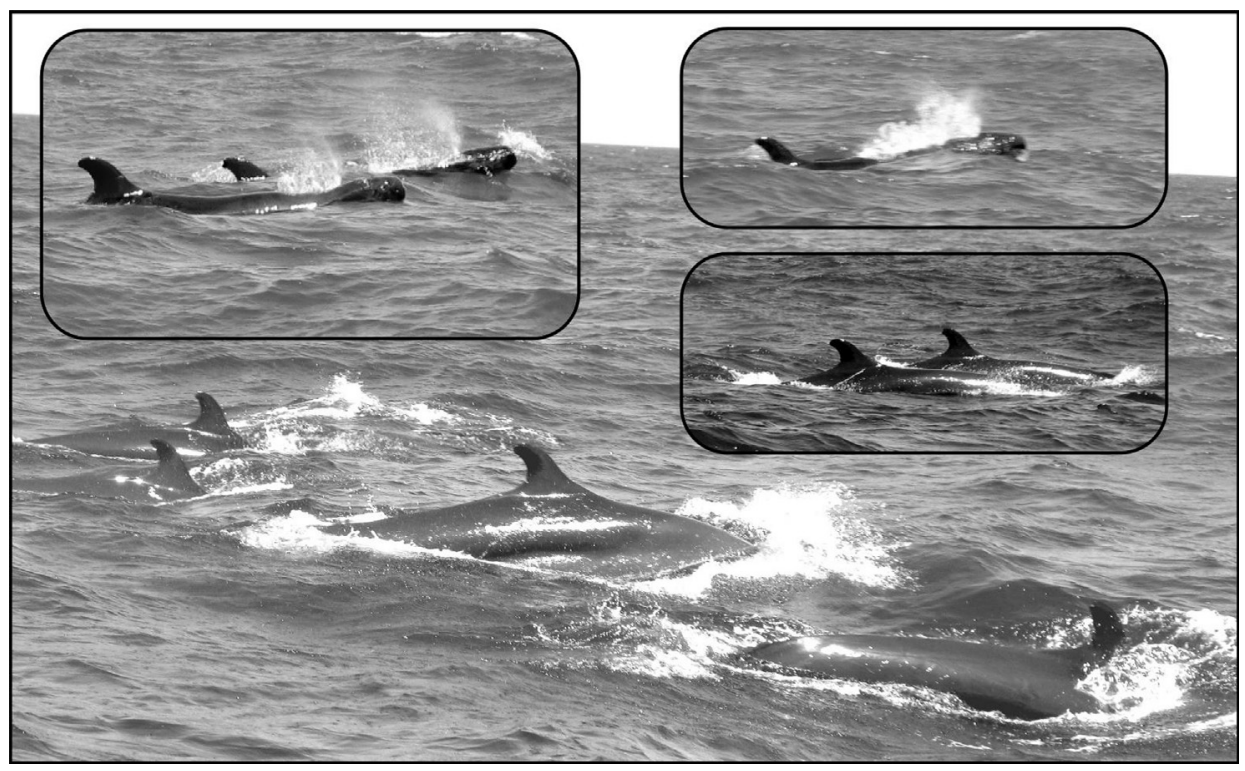

Figure 2. False killer whales sighted off the Santa Marta region.

Figure 3. Skin lesions in rough-toothed dolphins (ab) and a stranded humpback whale showing a perforation wound in the caudal peduncle (c-d).

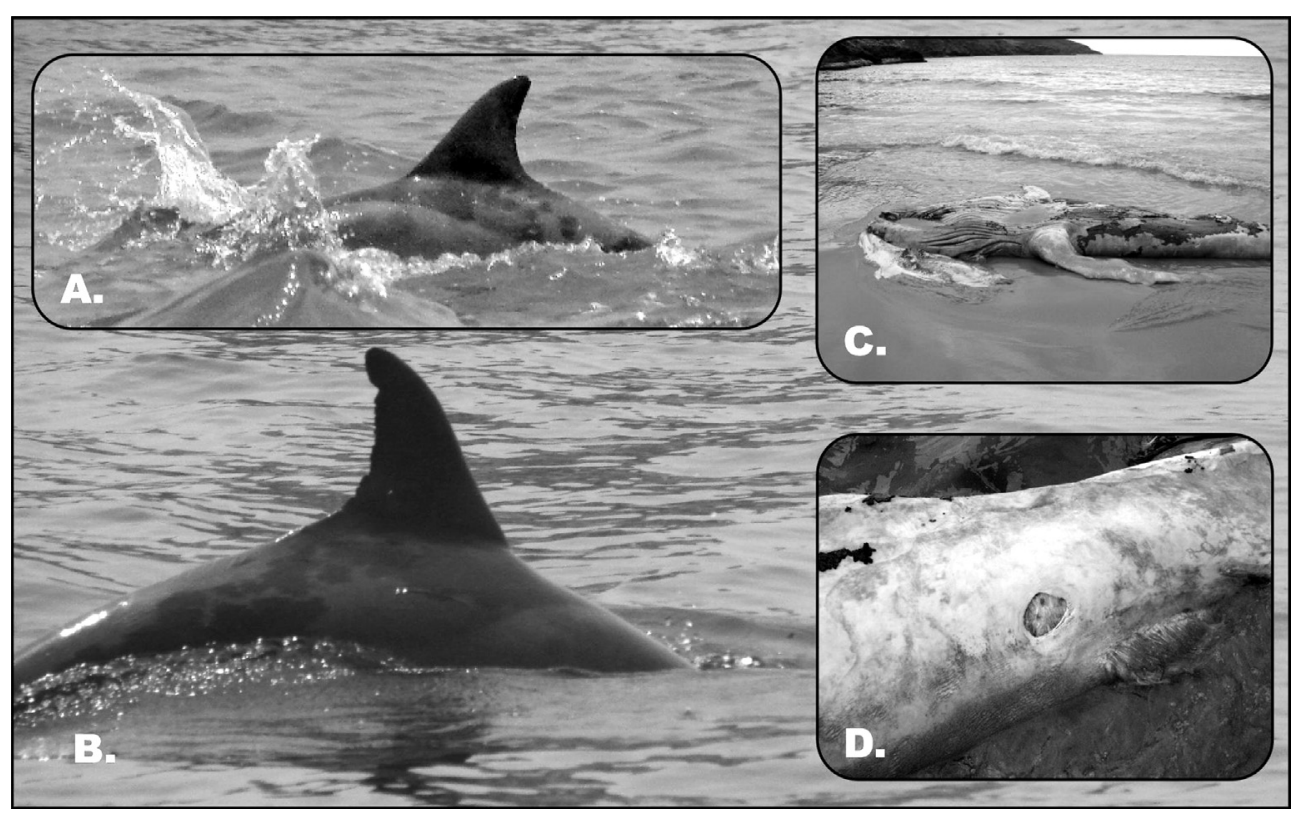

Atlantic spotted dolphin (Stenella frontalis) - The two sightings made in this study were located around the $50 \mathrm{~m}$ isobath (Table 1, Figure 1); in both occasions the animals appeared to be in transit through the zone. The group structure of the sighted animals contained adults and juveniles. This species is common in the Santa Marta region, having been previously reported by Vidal (1990), FlórezGonzález and Capella-Alzueta (1995), Pardo and Palacios (2006) and Jímenez-Pinedo and Domínguez-García (2007). According to Pardo and Palacios (2006) and BolañosJiménez et al. (200711), who worked previously in the Santa Marta region and in adjacent Venezuelan waters, respectively, the Atlantic spotted dolphin tends to use waters around the $200 \mathrm{~m}$ isobath, coming into shallower coastal zones sporadically. At least part of the population found in Venezuela displays a high site fidelity, with re-sightings separated by few days or even months (Bolaños-Jiménez et al., 2007'11). It is important to continue the studies on this species to determine the relationship of the animals seen off Santa Marta and those found in the Venezuelan waters as well as the stock structure in the southwestern Caribbean. Common bottlenose dolphin (Tursiops truncatus) Two incidental sightings were reported near the coast, in waters $10-20 \mathrm{~m}$ deep (Table 1 ), which is common

\footnotetext{
${ }^{11}$ Bolaños-Jiménez, J., Villaroel-Marin, A., Parsons, E.C.M. and Rose, N. (2007) Origin and development of whale watching in the state of Aragua, Venezuela: Laying the groundwork for sustainability. In Abstracts, Proceedins of the $5^{\text {th }}$ International Coastal and Marine Tourism Congress, 11-15 September, Auckland, New Zealand.
} 
for the species (Würsig and Würsig (1978). As the spatial distribution of cetaceans is highly correlated with areas of bathymetric relief (Mignucci-Giannoni, 1998; Oviedo et al., 2005; Bilgmann et al., 2007), we suggest that these animals may travel through the area and enter the bays, using them as resting or foraging places. This species, as the Atlantic spotted dolphin, has been reported several times in the region by Prieto-Rodríguez (1988), Vidal (1990), FlórezGonzález and Capella-Alzueta (1995), Pardo and Palacios (2006), Lozano (2007) and Jímenez-Pinedo and Domínguez-García (2007).

Rough-toothed dolphin (Steno bredanensis) - One sighting of the species with a high cohesion between the individuals that made up the group was observed (Table 1). The animals showed slow movements at the surface, which according with Würsig and Würsig (1978) suggest foraging behaviors. Despite the species' pelagic habits, the animals can have seasonal inshore movements related to prey concentrations (Longhurst and Pauly, 1987; Mignucci-Giannoni, 1998; Addink and Smeenk, 2001). Apparent skin lesions were observed (Figure 3a, b), which could have been caused by chemical or organic pollutants in the water (Van Bressem et al., 1999; 2003; 2007). More studies are required to determine the cause of these lesions and its pervasiveness in the population.

False killer whale (Pseudorca crassidens) - During the three sightings of the species (Table 1 ) the animals were traveling, except for one group observed in Neguanje Bay, which appeared to be feeding on surface fishes and showing behaviors indicative of subsurface foraging activities like strong movement of the caudal fin towards the water (Acevedo-Gutiérrez et al., 2007). Upwelling in the Santa Marta region offers enriched waters during the dry season and, according to fishery catch, prey availability is increased (Manjarrés et al., 19936; CPMO, $2007^{12}$ ). The ichthyic material collected by artisanal fisheries during the surveys was mostly albacores (Thunnus alalunga), frigate tunas (Auxis hazard), little tunnies (Euthynnus alletteratus), and sardines (Sardinella sp.), upon which the false killer whale and the roughtoothed dolphin may feed (Longhurst and Pauly, 1987; Addink and Smeenk, 2001).
In the Wider Caribbean, the false killer whale has been reported for Cuba, Saint John's in the Virgin Islands, Saint Vincent, Tobago, and Venezuela (MignucciGiannoni, 1998; Romero et al., 2001 ${ }^{13}$ ). In Colombian waters, one sighting had been previously reported near the oceanic archipelago of San Andrés and Providencia (Palacios et al., 199514; 199615; Pardo et al., 2009b). In addition, a stranded specimen was reported in the Santuario de Fauna y Flora Los Flamencos $\left(11^{\circ} 24^{\prime} \mathrm{N}, 7^{\circ} 07^{\prime} \mathrm{W}\right)$, to the northeast of Santa Marta, by Pardo et al. (2009a). The sightings presented here constitute the first live record of the species in the Santa Marta region and in the continental Caribbean coast of Colombia, adding it to the confirmed range of the species in the southwestern Caribbean.

The two sampling strategies used during the study, land-based monitoring and boat-based surveys, were previously employed by Pardo and Palacios (2006) and Jiménez-Pinedo and Domínguez-García (2007), having yielded useful results. However, given the limited financial resources for research in the region, it is suggested that future studies focus their efforts on coastal boat-based surveys to include a larger sampling area in deeper zones not accessible from the land stations. Incidental reporting by trained personnel and the use of platforms of opportunity has been shown to augment the data collected by directed studies.

The information presented here, together with the earlier results from Pardo and Palacios (2006), Jiménez-Pinedo and Domínguez-García (2007) and Lozano (2007), indicate the persistent presence of several species such as the common bottlenose dolphin, the Atlantic spotted dolphin and the roughtoothed dolphin. From these studies, no clear pattern of species occurrence in the zone emerges. However, species with both coastal and oceanic habits are present in the region, and appear to use it as a foraging ground or perhaps for transiting to other areas, according to the local availability of food. It is important to continue monitoring efforts in the region with long-term studies that may further contribute to the knowledge of the cetacean community of the southwestern Caribbean.

\footnotetext{
${ }^{12}$ Central de Pronósticos Meteorológicos y Oceanográficos-CPMO. (2007) Boletín meteomarino mensual del Caribe colombiano. Centro de Investigaciones Oceanográficas e Hidrográficas (CIOH). [PDF available from http:// http://www.cioh.org.co/dev/proserv/ boletinmet.html].

${ }^{13}$ Romero, A., Agudo, A.I., Green, S., Notarbartolo di Sciara, G. (2001) Cetaceans of Venezuela: Their distribution and conservation status. U.S. Department of Commerce, A technical report of the Fishery Bulletin 151: 61 pp. [Available from NMFS, Seattle, Washington, USA].

${ }^{14}$ Palacios, D., Gerrodette, T., Beltrán, S., Rodriguez, P. and Brennan, B. (1995) Cetacean sighting cruises off the Colombian Caribbean Sea and Pacific Ocean. Page 88 in Abstracts, Eleventh Biennial Conference on the Biology of Marine Mammals, 14-16 December 1995, Orlando, Florida, USA.

${ }^{15}$ Palacios, D., Rodríguez, P., Brennan, B.J., Beltrán, S., and Trujillo, F. (1996) Cetacean sightings during cruises in the southwestern Caribbean Sea. Page 76 in Programas y Resumenes, 7ma. Reunión de Trabajo de Especialistas en Mamíferos Acuáticos de América del Sur, 22-25 October 1996, Viña del Mar, Chile.
} 


\section{Acknowledgments}

The authors kindly thank the following institutions for their help in the coordination of the project: Jorge Tadeo Lozano University, INVEMAR, and Vida Marina diving center. Also thanks to Marie-Francoise Van Bressem, Elizabeth Hernández, Antonio Mignucci-Giannoni, Jaime Bolaños, Lenin Oviedo and especially to Julio Herrera and Daniel Palacios for their valuable comments on previous versions of this document. Fieldwork was supported by Anthony Combatt, Erwin González and the fisherman community of Gairaca Bay. Partial funding for this study was received from Cetacean Society International.

\section{References}

Acevedo-Gutiérrez, A., Brennan, B., Rodríguez, P. And Thomas, M. (1997) Resightings and behavior of false killer whales (Pseudorca crassidens) in Costa Rica. Marine Mammal Science 13(2): 307-314.

AdDink, M.J. AND SMEENK, C. (2001) Opportunistic feeding behavior of rough-toothed dolphins, Steno bredanensis off Mauritiana. Zoologische Verhandelingen 29: 37-48.

Andrade, G. (1988) Sierra Nevada de Santa Marta. Pages 321335 in Rouillard, P. (Ed.) Sierra Nevada: Santa Marta, Ciudad Perdida, Guajira. Editorial Colina., Medellín, Colombia.

AndRADE-Amaya, C. (2001) Las corrientes superficiales en la cuenca de Colombia observadas con boyas de deriva. Revista Académica Colombiana de Ciencias 25 (96): 321-335.

Bilgmann, K., Möller, L., Harcourt, R., Gibbs, S. and Beheregaray, L. (2007) Genetic differentiation in bottlenose dolphins from South Australia: association with local oceanography and coastal geography. Marine Ecology Progress Series 341: 265-276.

Bula-Meyer, G. (1990) Altas temperaturas estacionales del agua como condición disturbadota de las microalgas del Parque Nacional Tayrona, Caribe colombiano: Una hipótesis. Anales del Instituto de Investigaciones Marinas 19-20: 9-21.

Clapham, P. And Mead, J. (1999) Megaptera novaeangliae. Mammalian Species 604: 1-9.

Cuervo, A., Hernández, J. And Cadena, A. (1986) Lista actualizada de los mamíferos de Colombia. Anotaciones sobre su distribución. Caldasia 15(71-75): 471-501.

FAJARDO, G.E. (1978) Surgencia costera en las proximidades de la Península colombiana de la Guajira. Boletín Científico $\mathrm{CIOH}$ 2: 7-19.

Flórez-González, L. And Capella-Alzueta, J. (1995) Mamíferos acuáticos de Colombia. Una revisión y nuevas observaciones sobre su presencia, estado del conocimiento y conservación. Informe Museo del Mar 39: 1-29.

Flórez-González, L., Capella-Alzueta, J and Falk, P. (2004) Guía de campo de los mamíferos acuáticos de Colombia. Editorial Sepia Ltda., Cali, Colombia. 124 pp.

Jiménez-Pinedo, N. And Domínguez-García, C. (2007) Presencia y área de ubicación de cetáceos en el Parque Nacional Natural Tayrona, Magdalena-Colombia. Thesis. Universidad Jorge Tadeo
Lozano. Bogotá, Colombia. 145 pp.

LONGhurst, A. AND PAULY, D. (1987) Ecology of tropical oceans. Academic Press. San Diego, USA.

Lozano, A. (2007) Avistamiento de cetáceos desde puntos fijos en la región de Santa Marta (Bahía de Gaira y Santa Marta) durante el segundo semestre del año 2005. Thesis. Universidad Jorge Tadeo Lozano. Bogotá, Colombia. 66 pp.

Mignucci-Giannoni, A. (1998) Zoogeography of Cetaceans off Puerto Rico and the Virgin Islands. Caribbean Journal of Science 34(3-4): 173-190.

Oviedo, L., Silva, N., Bermudez, L. And Odell, D. (2005) Distribution of bottlenose dolphin (Tursiops truncatus) on the East coast of Isla Margarita and the Los Frailes Archipielago, Venezuela. Aquatic Mammals 31(4): 442-446.

Pardo, M. And Palacios, D. (2006) Cetacean occurrence in the Santa Marta region, Colombian caribbean, 2004 - 2005. Latin American Journal of Aquatic Mammals 5(2): 129-134.

Pardo, M.A, Jiménez-Pinedo, N.C. And Palacios, D.M. (2009a) The false killer whale (Pseudorca crassidens) in the southwestern Caribbean: First stranding records in the Colombian waters. Latin American Journal of Aquatic Mammals 7(1-2): 63-67.

Pardo, M.A, Mejía-Fajardo, A., Beltrán-Pedreros, S., Trujillo, F., Kerr, I. AND Palacios, D.M. (2009b) Odontocete sightings collected during offshore cruises in the southwestern and western Caribbean Sea. Latin American Journal of Aquatic Mammals 7(1-2): 57-62.

Prieto-Rodriguez, M. (1988) Reporte de algunos cetáceos del Caribe colombiano. Boletín de Facultad de Biología Marina 8: 30-40.

Swartz, S., Cole, T., McDonald, M., Hildebrand, J., Oleson, E., Martínez, A., Clapham, P., Barlow, J. And Jones, M.L. (2003) Acoustic and visual survey of Humpback whale (Megaptera novaeangliae) distribution in the Eastern and Southeastern Caribbean Sea. Caribbean Journal of Science 39(2): 195-208.

Van Bressem, M.F., Van Waerebeek, K. And Raga, J.A. (1999) A review of virus infections of cetaceans and the potential impact of morbilliviruses, poxviruses and papillomaviruses on host population dynamics. Disease of Aquatic Organisms 38: $53-65$

Van Bressem, M.F., Gaspar, R. and Aznar, J. (2003) Epidemiology of tattoo skin disease in bottlenose dolphin, Tursiops truncatus from the Sado estuary, Portugal. Disease of Aquatic Organisms 56: 171-179.

Van Bressem, M.F., Van Waerebeek, K., Reyes, J.C., Félix, F., Echegaray, M., Siciliano, S., Di Beneditto, A.P., Flach, L., Viddi, F., Avila, I.C., Herrera, J.C., TobóN, I.C., Bolaños-JimÉnez, J., Moreno, I., Ott, P., Sanino, J.P., Castineira, E., Montes, D., Crespo, E., Flores, P., HaAse, B., Mendoça de Souza, S., Laeta, M. and Fragoso, A.B. (2007) A preliminary overview of skin and skeletal diseases and traumata in small cetaceans from south American waters. Latin American Journal of Aquatic Mammals 6(1): 7-42.

VIDAL, O. (1990) Lista de los mamíferos acuáticos de Colombia. Informe del Museo del Mar 37: 1-18.

WÜRSIG, B. AND WÜRSIG, M. (1978) Behavior and ecology of the bottlenose dolphin, Tursiops truncatus, in the South Atlantic. Fishery Bulletin 77(2): 399-411. 